\title{
Effects of Technology-Assisted Learning on Students' Learning in the Chadian Education System
}

\author{
Nehemie Ndiguinta Djimadoumngar. Yu Ruiwei \\ Department of Teacher Education, Huzhou University. Huzhou, China
}

\begin{abstract}
It is undeniable fact that technology plays a critical role in the growth of today's nations. The demand of today, technology cannot be blotted out. Technology lays pressure on demand in every aspect of our daily life. One key area is education. Different software, technological approaches, technological pedagogies, and methods are evolving just to facilitate teaching and learning. The study, therefore, sought to find out whether Technology Assisted Learning (TAL) improves students learning in the Chadian Education system? As a result, there will be simple access, high-quality teaching and learning, infrastructure, and managerial efficiency. Despite this, many academic institutions have yet to fully appreciate the promise of TAL in teaching and learning. The investigation was conducted using a mixed technique approach. A questionnaire was utilized to gather information from 288 respondents: 108 lecturers and 180 students from Ndjamena University. Interviews were also held with 4 management and ICT professionals. According to the study's findings, TAL has not been widely integrated into Ndjamena University's learning activities. Frequent power fluctuations, a lack of maintenance, poor internet speed, a lack of pedagogical models for how to utilize TAL in teaching and learning, and inadequate ICT skills of lecturers and students to fully integrate ICT were some of the issues noted. To help practical integration of TAL in teaching and learning, the research advised that, ICT training for lecturers and students is key. ICT infrastructure provision and maintenance, as well as ICT service delivery, should be prioritized. The complete implementation and usage of ICT facilities and services will not only transform teaching and learning at N'djamena University, but it will also help lecturers and students improve their intrinsic scientific inquiry mind and critical thinking talents. There is also the need to call on stakeholders such as IT service providers and the government to support the institution. Keywords: Technology-Assisted Learning, Students, Learning, Chadian Education System
\end{abstract}

DOI: $10.7176 / \mathrm{JEP} / 13-3-07$

Publication date: January $31^{\text {st }} 2022$

\subsection{INTRODUCTION}

Education has perhaps never needed technology more. Due to the fast spread of COVID-19, 192 nations shuttered schools, and 91 percent of students were sent home in the spring of 2020. (IDB, 2020). A global distant learning experiment has begun. Aside from making education more efficient and effective, technology is a key medium that enables education to happen and continue even in times of crisis. Education was enabled by technology. Suddenly, education is tech-driven.

In our ever-changing technological society, young people are becoming experts and geniuses in this field surpassing many adults, they can be seen as digital natives (Fish, 2009). Therefore, the education system estimates stress and the need to use technology in schools. There are many tools and procedures that educators can use to improve student learning and education generally. Advances in information and communication technology have opened up intriguing possibilities for educational reform. Instructors are increasingly utilizing available technologies to improve their students' learning experiences, such as by creating vivid, playful, interactive learning environments that support multimedia presentations, adaptive online exercises, and virtual discussions, all while giving students more control over their learning and pacing. The Internet is especially important because it offers a globally accessible and easy-to-use platform that facilitates a broad range of learning and knowledge dissemination activities. Not unexpectedly, the usage of Web-based courses and training programs has developed at a fast rate (Allen \& Seaman 2006), allowing instructors to devote more time and attention to other key learning activities while preparing and administering courses. This emergence of technology in the educational sector has brought intervention programs such as Computer Assisted Learning (CAL), Digital Learning (DL), Technology Enhanced Learning (TEL), and more. All these interventions are meant to improve teaching and learning in the technological era.

While research on the impacts of technology in the classroom is growing at a fast pace, there seems to be much disagreement on whether technology has had a meaningful influence on student accomplishment.

According to what we know, technology is undoubtedly being used in the classroom to assist kids in developing a certain set of abilities necessary for 21 st-century success. Additionally, technology enables students to study both inside and outside of a traditional brick-and-mortar classroom. While these are only two of the numerous reasons to embrace technology in the classroom, knowing the features and practicalities of this kind of instruction is equally, if not more, vital. 


\subsection{Motivation for the Study}

Most of Chad's initiatives involve training and continuing education through ICT. Although the introduction of technology in the education system has its advantages and disadvantages it cannot be said that it is impossible to use ICT in the education system, of course, is going to be difficult but not impossible. The Ministry of Education is currently exploring new goals and initiatives to establish programs that benefit teachers and students. The main obstacle to overcome is the need for funding (financial need

With the government of Chad willingness to expand the use of information and communication technologies, as evidenced by the computerization of several ministries, the organization of major events such as the first International Exhibition of Information and Communication Technology in September 2014, and the launch of the project to build the African Center for Telecommunications and Information (ACTI), it is critical to integrate early ICT into schools (Leouro et al., 2018). In 2011, the Chadian Economic, Social, and Cultural Council advocated a gradual adoption of ICT in secondary school to promote learning in its policy letter on the education system. UNESCO (United Nations Educational, Scientific, and Cultural Organization) pushed governments to teach computer science in high school as early as 1996 (Leouro et al., 2018) Indeed, this instruction will expose students to computers and help them improve their critical thinking talents, their technological abilities, their social behavior, and their capacity to act and work independently and collaboratively. Despite all these investments in technological infrastructure, equipment, and professional development to advance education in Chad, it is clear that the potential for technology to support students' learning and teachers' delivery has not been realized (Leouro et al., 2018))

\subsection{LITERATURE REVIEW}

\subsection{Definition of key terms}

To enhance an effective understanding of the study, key terms have been explained. These terms are Information and Communication Technologies (ICTs)

\subsubsection{Technology}

\subsubsection{Technology Assisted Learning (TAL)}

Technology-Assisted Learning (TAL) is a curriculum that integrates modern technology with ordinary learning. In addition to academics, the curriculum teaches students about cyber safety and digital etiquette. Technological tools are both adopted by the teacher and the learner under the scope of teaching and learning to achieve an objective.

\subsubsection{Information and Communication Technologies (ICTs)}

Beldarrain (2010) describes ICTs as a collection of technologically based tools and resources used in communication, as well as for the generation, diffusion, storage, and administration of information. Ololube et al. (2012) also believe that ICTs refer to technological advancements that provide a wealth of global resources and a coordinated society that facilitates the transmission of materials for interactive conversations, research, and information exchanges. Chifwepa (2008) adds his viewpoint by describing ICTs as a heterogeneous collection of technical instruments and materials used to transmit, generate, disseminate, store, and manage information.

\subsubsection{Learning}

On the other hand, learning is the process of acquiring information or skills via study, experience, or instruction (WWD, 2019). While learning is frequently defined as the process of acquiring information, beliefs, and ideas related to sustainable development, it also emphasizes the process of changing minds and the learner's active participation in issues relevant to a more sustainable future (Tibury, 2011).

\subsection{Dimensions of Technology-Assisted Learning}

As a result of its significant and long-lasting effects on education, technology-assisted learning has garnered great interest from scholars and educators alike. Student achievement and find that both modes of learning provide equivalent results. Similarly, (Leouro et al., 2018) demonstrate that the performance of students who use technology-assisted learning and those who study via face-to-face education is similar. Students in open labs experience more anxiety than those in closed laboratories and connect the difference to teachers' perceived availability. The employment of technology in education is now enshrined in legislation. It is no longer a choice or an option; it is a necessity. Both teaching and learning will take place in a technology-infused learning environment. Recently, technology has become an integral aspect of assessment, as states steadily transitioned their compulsory state tests away from paper and pencil and into digital formats. Switching to a digital format necessitated districts developing the infrastructure necessary to support the new format, which remains a work in progress. The question thus is not whether technology practices will be included in future TLPs, but rather whether the technology practices employed in the classroom today will stay unchanged.

Individuals might change the learner definition from one in which the teacher's function is to impart information to one in which students drive their learning via self-instruction utilizing technology under the expert direction of the instructor (Cicconi, 2014). Today's and future students approach the classroom as learners who 
have grown up with personalized mobile technology at their fingertips. They are referred to as the iGeneration or digital natives. They are pupils who, from an early age, have played, gamed, texted, or conversed with their own or their parents' cellular device (Rosen, 2011). Similarly, they have viewed films and listened to music on their mobile phones, iPads, or tablets, and have had the chance to experience writing code and printing with a 3D printer. They spend every waking minute of the day immersed in media and technology (Rosen, 2011). At the moment, digital natives live in a world in which their cellular devices act as a little personal computer, enabling them instant access to information. Indeed, many of these middle and high school kids may move between various devices, such as their laptop and mobile phone, take an online course, and even participate in an interactive computer game with a student stationed across the nation (Rosen, 2011). Will instructors be expected to provide all curriculum online? Is it mandatory for school districts to give access to every Web 2.0 technology accessible on the internet? Utilizing technology to improve education does not imply offering technology for the sake of technology (Rosen, 2011). Technology for the sake of technology leaves far too many whiteboards, document cameras, and laptop carts underutilized in the classroom, or students viewing countless instructive films without engaging in-class discussion or making connections to the information. According to Rosen (2011), instructors may communicate information more effectively and efficiently to all students by using alternate forms of content or audio and videorelated resources. This way of using technology coincides with the UDL concept by giving numerous representations of material; yet, for students to receive knowledge from these sources, they must actively seek information rather than passively observe or listen. Many audio/visual/technological resources may be used in several ways to assist instructors in teaching and students in learning. The most straightforward visual depiction is by the use of an overhead projector and transparencies to exhibit text, graphs, graphics, pictures, and cartoons, among other things. Thus, video documentaries and audiotapes are used that pupils can see and comprehend theoretical topics such as human anatomy or the eclipse phenomenon. Teachers can effectively use ICT tools such as computers, the internet, and mobile phones, as well as a variety of teaching aids and online services such as email, online chat, Facebook, Twitter, forums, blogs, slideshows, search engines, interactive whiteboards, and videoconferencing, to communicate with students, ask questions, resolve doubts, answer queries, assign assignments, send reminders, coordinate group activities, and even have an out-of-class discussion. These virtual encounters foster a continuous exchange of views, comments, reflections, and feedback, transcending time, distance, and even students' shyness.

\subsection{Technology integration into Education}

In a broad sense, technology integration may be defined as the process of boosting learning via the utilization of current tools, equipment, and materials, including electronic media (Okojie et al., 2019). It entails the management and coordination of instructional tools and resources available to support learning. Additionally, it entails the selection of appropriate technology based on students' learning requirements, as well as instructors' capacity to modify such technology to match certain learning activities. Okojie et al., continue to explain that it requires instructors to be able to choose appropriate technology while preparing lessons. Additionally, it demands instructors to use suitable technology for delivering and evaluating education, as well as for doing follow-up learning activities. A wide concept of technology integration in education will assist instructors in developing a coherent approach to technology integration.

The technology integration concept can further be explained as the process of teaching a subject that already exists in the curriculum using technology as an educational tool (Yemothy, 2012). Thus, technology serves as a medium for the transmission of instructional content. "Technology integration is the process of utilizing technology to support learning across several mediums, to create chances for student-centered learning, to engage learners, and to accommodate learners' differentiation and learning preferences" (Yemothy, 2012). According to Davies and West (2013), technology integration is "the effective use of instructional technology to achieve desired learning outcomes." Educational technology is defined as "any tool, piece of equipment, or device-electronic or mechanical - that can be utilized to assist students in achieving a certain learning objective." Educational technology encompasses both instructional technologies used by teachers and learning technologies used by students to meet learning objectives. Thus, technology integration is nothing more than the incorporation of technologies or media into the process of teaching and learning.

There are several ways in which technology may be integrated into the educational process. While just a handful of these methods are given here, new technological tools and concepts arise regularly. 
2.3.1 Online Learning and Blended Classrooms

2.3.3 Game-Based Learning and Assessment

2.3.4 Learning with Mobile and Handheld Devices

2.3.5 Instructional Tools like Interactive Whiteboards and Student Response Systems

2.3.6 Web-Based Projects, Explorations, and Research

2.3.7 Student-Created Media like Podcasts, Videos, or Slideshows

2.3.8 Collaborative Online Tools like Wikis or Google Docs

\subsection{Technological Pedagogical Content Knowledge (TPACK) Framework}

A teacher must possess both topic and pedagogical competence to carry out the teaching-learning process successfully. As Shulman proposed, this resulted in the concept of 'pedagogical content knowledge' (1986). Recognizing the significance of technology, Mishra and Koehler combined the terms 'technology' and 'pedagogical content knowledge' from Shulman, resulting in the coining of the term 'technological pedagogical content knowledge' and the abbreviation TPACK. TPACK is a well-known and frequently used framework that guides instructors in integrating technology into their classroom instruction. TPACK categorizes teacher knowledge into three distinct components: technological pedagogical knowledge (TPK), technological content knowledge (TCK), pedagogical content knowledge (PCK), and Technological Pedagogical Content Knowledge (TPCK) (TPACK). TPACK is characterized as "a framework of educator knowledge for integrating technology." Within the context of TPACK, teacher knowledge is characterized as a complex interaction and intersection of three bodies of knowledge: content, pedagogy, and technology" (Koehler and Mishra, 2008). TPACK is a well-balanced and intelligent combination of pedagogy, material, and technology that enables the successful integration of technology into teaching and learning (Thompson and Mishra, 2006). Thus, TPACK is composed of three core competencies: Technological Knowledge (TK), Pedagogical Knowledge (PK), and Content Knowledge (CK), as well as four integrated competencies: Technological Pedagogical Knowledge (TPK), Technological Content Knowledge (TCK), Pedagogical Content Knowledge (PCK), and Technological Pedagogical Content Knowledge (TPK) (TPACK)

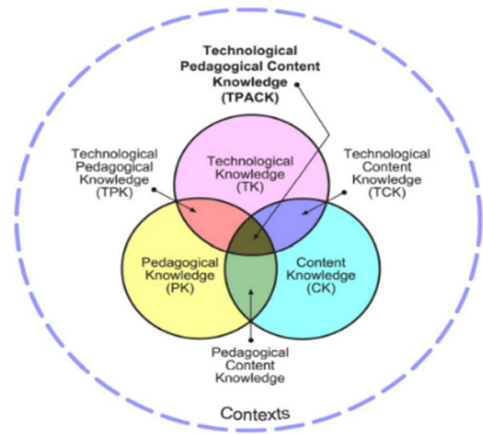

The TPACK framework

Technological knowledge (TK): Numerous technologies (digital equipment such as computers, cameras, and mobile devices, as well as digital tools such as application software, social media, and so on) are accessible today for teaching and learning. A teacher attempting to incorporate technology must have a working knowledge and grasp of a variety of technologies (Koehler and Mishra, 2008). Simply knowing about technologies is insufficient; the teacher must also be capable of operating and successfully utilizing technology in the classroom. This teacher's technological understanding is referred to as technological literacy (TK).

Pedagogical knowledge (PK): Before beginning to teach, a teacher is expected to have pedagogical understanding. The science of teaching is called pedagogy. The term pedagogy refers to teachers' knowledge of teaching methods, teaching approaches, learning theories, teaching styles, learning styles, classroom management, organizing learning experiences, evaluating methods, current trends in teaching and learning, learner psychology, and inclusive practices, among others. The term pedagogical knowledge refers to the teacher's understanding of many facets of teaching (PK).

Content Knowledge (CK): Without a deep comprehension of the subject/topic being taught, a teacher will be unable to design a successful teaching session. Apart from content/topic expertise, teachers should be up to date on their subject. Content knowledge refers to the teacher's understanding of the subject area, which includes terminology, facts, concepts, principles, theories, and laws, among others (CK).

Technological Pedagogical Knowledge (TPK): Technology Integration Needs Instructors to Consider the Link Between Technology and Pedagogy (TPK): Technology integration requires teachers to consider the relationship between technology and pedagogy. This is referred to as technology pedagogical content knowledge for teachers (TPK). To educate, you must choose an appropriate technology based on the pedagogy chosen for a given subject. A specific technology may not always be appropriate for a certain teaching style and vice versa. As a result, you 
must exercise caution while picking technology that is appropriate for a certain teaching method/approach. The choice of technology is also contingent on a variety of other pedagogical considerations.

Technological Content Knowledge (TCK): When picking a technology, it is necessary to take into account the content/topic being transacted (Koehler and Mishra, 2008). For example, you may teach a mathematics topic using the lecture technique and then have the youngsters complete some mathematical questions. In general, students use their notebooks to answer mathematical problems. However, you may also utilize technology. For instance, you may utilize any application program that allows students to alter 'values' in the software and observe the outcomes. This enables pupils to repeatedly modify 'values.' For example, students can alter two numbers while adding them and observe the effect on the results. Additionally, this assists pupils in identifying their errors when completing tasks. As a result, the technological selection is also determined by the content. Thus, the knowledge of the instructor regarding the most appropriate technology for transacting a certain subject is referred to as Technological Content Knowledge (TCK).

Pedagogical Content Knowledge (PCK): When it comes to teaching a subject, you are free to use any approach. However, keep in mind that not every pedagogy (teaching style) is appropriate for teaching all of a subject's elements. As a result, you may use a variety of teaching approaches to impart knowledge about a variety of subjects. And to choose a certain pedagogy, you should have a firm grasp on a variety of topics, including teaching methods, learning experience organization, assessment procedures, and classroom management approaches. The process of selecting an acceptable pedagogy for a certain material is referred to as Pedagogical Content Knowledge (PCK).

Technological Pedagogical Content Knowledge (TPK): TPACK is a sort of emergent knowledge that transcends all three "core" components (content, pedagogy, and technology). Technological pedagogical content knowledge is a type of knowledge that comes through interactions between content, pedagogy, and technology (Kotler \& Mishra 2009). TPACK is distinct from an individual understanding of the three ideas that underpin really effective and highly proficient teaching using technology. Rather than that, TPACK is the foundation for effective technology-assisted instruction, requiring an understanding of how concepts are represented using technologies; pedagogical techniques that employ technology constructively to teach content; an understanding of what makes concepts difficult or easy to learn, and how technology can assist students in resolving some of their difficulties; an understanding of students' prior knowledge and epistemological theories; and an understanding of how technologies can assist students in resolving some of their difficulties (Kotler \& Mishra 2009). By combining knowledge of technology, pedagogy, and content, experienced instructors incorporate TPACK into their instruction at all times. Each circumstance that instructors face is a unique combination of these three criteria, and as a result, no one technical solution applies to every teacher, every course, or every perspective on teaching. Rather than that, the solution lies in the teacher's capacity to negotiate the spaces established by the three aspects of content, pedagogy, and technology, as well as the intricate interactions between these elements in particular circumstances. Ignoring the intrinsic complexity of each piece of knowledge or the intricacies of the interactions between the pieces of knowledge might result in simplistic solutions or failure (Kotler \& Mishra 2009). Thus, instructors must cultivate fluency and cognitive flexibility not just in the three critical domains ( $\mathrm{T}, \mathrm{P}$, and $\mathrm{C})$, but also in the way these domains and contextual aspects interact, to design effective solutions. This is the type of indepth, adaptable, pragmatic, and nuanced understanding of technology-assisted instruction that we included into our consideration of TPACK as a professional knowledge construct (Kotler \& Mishra 2009).

\subsubsection{Implications of TCPK}

The intricacy of technology integration stems from an understanding of the deep linkages of knowledge that exist between these three components and the intricate ways in which these components are implemented in diverse and dynamic classroom settings. There is no single technological solution applicable to every teaching, every subject, or every view of learning (Mishra \& Koehler, 2006). According to Fathima (2013), effective teaching should result in the display of new concepts and the development of sensitivity to the dynamic nature, as well as the transactional relationship, between the material, the strategy, and the technology to be used. Additionally, the TPACK framework enables the promotion of research in teacher education, professional development, and teachers' technology use. It provides perspectives on a complicated topic such as technology integration which may now be analyzed and developed. Additionally, it enables teachers, researchers, and teacher educators to go beyond simplistic methods that see technology as an "add-on" and instead focus on the linkages between technology, content, and pedagogy as they emerge in classroom environments.

\subsection{Challenges facing Technology Integration}

Despite the numerous benefits of incorporating technology into teaching and learning, the system faces a slew of problems. According to Koehler et al. (2014), utilizing technology for teaching and learning presents several obstacles, which are exacerbated by the daily arrival of new technologies. Numerous difficulties have been highlighted through a study of prior empirical investigations. A few of these obstacles were discussed below.

\subsubsection{Teacher Confidence}

Numerous researches indicate that one of the barriers preventing teachers from incorporating ICT into their 
classroom instruction is a lack of confidence. This, according to Dawes (2001), is a contextual component that might operate as a barrier. It has been stated that teachers' lack of confidence and expertise with technology affects their willingness to incorporate ICT into the classroom (Balanskat et al., 2006). On the other hand, instructors who are confident in their use of technology in the classroom appreciate the value of ICT. Becta discovered that instructors who are confident in their use of ICT recognize that technologies are beneficial in their teaching and personal work and that they should continue to expand their use in the future.

\subsubsection{Competence of the teacher}

According to Balanskat et al. (2006), "in Denmark... many teachers continue to avoid using ICT and media in teaching situations due to a lack of ICT skills rather than for pedagogical/didactics reasons," whereas "in the Netherlands... teachers' ICT knowledge and skills are no longer regarded as the primary barrier to ICT use" (p. 50). Thus, a lack of teacher competence may be a significant impediment to integrating technologies into education. It may also be a factor in reluctance to change.

\subsubsection{Lack of access}

Numerous research studies reveal that a lack of resources, particularly at home, is another difficult obstacle that discourages teachers from integrating new technology into education, particularly science education, as illustrated in the following discussion. Numerous research studies revealed a variety of factors for the lack of access to technologies. Teachers complained in Al-Alwani's (2000) study about how difficult it was to always have access to computers. The author cited reasons such as "computers had to be reserved in advance, which teachers frequently forgot to do, or they could not reserve them for multiple times in a row when working on multiple projects with pupils" (p. 50). In other words, a teacher would be unable to access ICT materials because the majority of these were shared with other teachers. According to Becta (2004), inaccessibility to ICT resources is not always due to a lack of hardware, software, or other ICT items poor the school. It could be the result of a variety of problems, including inefficient resource management, low-quality hardware, improper software, or a lack of personal access for teachers (Becta, 2004). Barriers to teachers' access to new technology are numerous and vary by nation. According to Balanska et al., (2006) European survey, the primary obstacle to utilizing ICT in education is a lack of access, and instructors identified a variety of difficulties to using ICT in the classroom, including a shortage of computers and insufficient content. Again Al-Aawani asserted that lack of computers, the age or slowness of ICT systems, and a paucity of instructional software in schools all contributed to the failure of ICT to be successfully integrated into science teaching in Turkish schools. Similarly, Al-Alwani (2005) discovered that lack of Internet connection throughout the school day and a shortage of hardware hampered technology integration in Saudi schools. Recent research on Syrian schools found that a lack of computer resources was one of the primary hurdles to integrating technology into the classroom (Blanaska et al., 2006).

\subsubsection{Lack of technical support}

Teachers cannot be expected to overcome hurdles to ICT use without adequate technical assistance in the classroom and access to whole-school resources. Pelgrum (2001) discovered that one of the biggest hurdles to ICT adoption in education, according to elementary and secondary teachers, was a lack of technical help. Technical difficulties were identified as a significant barrier for teachers in Korte and Husing's (2007) study. These technological impediments included waiting for websites to load, being unable to connect to the Internet, printers failing to print, computers misbehaving, and teachers working on outdated machines. "Technical obstacles harmed the lesson's seamless delivery or the natural flow of classroom activities" (Tropacki, p. 43). Korte and Hüsing (2007) claimed that ICT support or maintenance contracts in schools enable instructors to use ICT in the classroom without having to spend time troubleshooting software and hardware issues. According to Tropacki (2006), integrating ICT into scientific education requires the presence of a technician, and if one is not accessible, a lack of technical assistance might be an impediment. In Turkey, Toprakci (2006) discovered that a lack of technical assistance was one of two important hurdles to integrating ICT into scientific instruction in schools, which might be classified as "severe." In Saudi Arabia, science instructors might agree to include computers in scientific instruction if they were not concerned about technical support or hardware issues (Korte and Husing, 2007). Toprakci (2006) suggested that regardless of the level of technical assistance and access available to teaching staff, whether they have twenty years of experience or are new to the field, technological issues create impediments to instructors delivering scientific classes smoothly.

\subsubsection{Lack of policy initiatives}

A significant impediment to successful ICT integration in public schools is a lack of well-defined educational policies and plans that specifically address ICT integration. Similarly, educational policy should include mechanisms for rewarding and encouraging teachers' use of ICT in the classroom, and it should be a component of teachers' professional development. To support the use of ICT in education, ICT policies and strategies must be devised. Tondeur et al., 2008) placed a premium on schools developing a common vision for ICT adoption, establishing consistent methods, and requiring instructors to examine school policies regarding ICT implementation. ICT policy contributes to the formation of a school culture conducive to the efficient use of ICT. To implement an ICT-based curriculum for the use of ICT in education, a strategic strategy, and planning process 
are necessary (Tondeur et al., 2008). However, the reality is that many nations' educational changes addressing the use of ICT lack a sound justification. Rather than concentrating on teachers' efforts to incorporate ICT into their teaching practices, instructors lack an understanding of how to use ICT successfully in the classroom (Korte and Hüsing, 2007). Often, integration of ICT is interpreted as imprecise conceptualizations of the desired learning facilitated by technology. There is a lack of consensus about the use of ICT in education among policymakers and educators (Hui, Hu, Tam, \& Milton, 2008). As a result, it appears as though there is no sense in installing ICT infrastructure in schools unless a sound explanation is established (Twining, 2007). A unified vision for the use of ICT in teaching and learning is critical. Teachers involved in the development of ICT planning have a beneficial role in the creative use of ICT. Setting goals and providing tools to accomplish them are critical when developing ICT policies and planning for schools (Twining, 2007).

\subsubsection{Lack of Training}

The research on challenges to ICT integration has mostly focused on teachers' lack of training or professional development. One of Belgium's findings was the dearth of possibilities for instructors to receive ICT-based training. Similarly, Turkish school instructors lack proper ICT training (Lim \& Khine, 2006). Concerns about teacher training include adequate time for training, didactic instruction to connect curriculum to ICT, and fundamental ICT training skills. It is critical to offer instructors pedagogical training rather than simply teaching them how to utilize ICT technologies (Lim \& Khine, 2006). Teachers who have attended ICT-related professional development courses lacked the confidence to integrate ICT into their lessons. They said that these courses focused mostly on fundamental ICT skills and did not educate teachers on how to integrate ICT tools into their teaching. As a result, ineffective teacher education programs do not educate teachers to design successful ICT-based curricula or to use these technologies effectively in their classroom practice (Tondeur, Keer, \& Valcke, 2008). However, some initial training is necessary for teachers to learn fundamental computer skills and knowledge; this will aid in altering their attitudes regarding the use of ICT in the classroom (Becta, 2004).

\subsection{Impacts of Technology Assisted Learning on Education}

The 1990s were the decade of computer communications and information access, with the popularity and accessibility of internet-based services such as electronic mail and the World Wide Web being particularly notable (WWW). Simultaneously, the CD-ROM became the industry standard for packaged software distribution (replacing the floppy disk). As a result, educators began to place a higher premium on the use of technology to enhance student learning as a justification for investment. Any discussion of the employment of computer systems in schools must begin with an appreciation for the relationship between schools, learning, and computer technology. Numerous studies have demonstrated the benefits of incorporating technology into classroom learning. Technology may be utilized to build meaningful projects that encourage critical thinking and problem solving among pupils. The educational environment may be restructured and redesigned using technology to foster the development of higher-order thinking abilities (Kurt, 2010). Additionally, technology facilitates student cooperation. Collaboration is an extremely successful method of education. Students collaborate to produce projects or they might learn from one another by reading their colleagues' work (Keser et al., 2011).

One research was undertaken to investigate whether or not Wiki technology may help students improve their writing abilities in a college English as a foreign language writing class discovered benefits to adopting Wiki technology. Students were asked to join a Wiki page where they could create and upload passages, as well as read and reply to their classmates' passages. Students who took part in the study indicated that obtaining quick feedback from the teacher was an advantage of this mode of instruction. Additionally, students indicated that they learned vocabulary, spelling, and sentence structure by reading their peers' work (Lin \&Yang, 2011). Another research examined pre-service teachers' experiences integrating technology into arithmetic classrooms. The study demonstrates a beneficial effect on student mathematics learning. The pre-service instructors noticed that the internet supplied arithmetic tasks at various levels, allowing pupils to study at their own pace. The findings indicated that students were interested during math sessions that used technology and that they were able to discuss what they learned the next day. The teachers were taken aback by the students' ability to recall the lesson. Some pupils who took part in the courses claimed that the computer-aided them in comprehending what the teacher was saying. Technology can be used to create a more interactive and meaningful math lesson (Herron, 2010).

Another research discovered that combining technology and peer-led literary discussions can result in greater student engagement and motivation. Wikis, online literature circles, and online book clubs are all examples of technology employed in these small group discussions of literature. Students were able to connect with readers from different schools, states, and even nations using these tools. This form of technology provides a quantifiable and motivating method of exposing pupils to other ideas and cultures. These online discussions of literature have the potential to develop a feeling of community and healthy social connection (Coffey, 2012). Van Meter pupils utilize their laptops to access virtual reality applications, create Prezi slideshows, YouTube videos, and read and write blogs. At one school, a fifth-grade girl emphasized how much she enjoyed presenting and demonstrating what she could accomplish with technology. The kids at Van Meter are ecstatic about the learning opportunities 
enabled by the computers, as seen by their engagement in learning. Students are allowed to develop their talents and qualities via participation in activities about which they are enthusiastic. The learning is instantaneous, motivating, and pertinent. They are interacting and exchanging ideas through technology, conducting independent research, adapting to new settings, and taking control of their learning (Miller, 2011). Additionally, they had superior arithmetic abilities. ICT has a favorable influence on student learning and should be included in classroom education (Bulut \& Delen, 2011). According to research done by Baytak et al., the majority of students agree that integrating technology into the classroom curriculum improves their learning. Students who took part in the study stated that using technology in class makes studying more enjoyable and enables them to learn more. They thought that technology enhances the educational experience by making it more fascinating, engaging, and participatory. Today's children like to learn via doing, participating, and exploring (Baytak et al., 2011).

Technology has the potential to open the keys to learning for all kids. This includes pupils with disabilities. The Etiwanda School District in California has launched a district-wide technology integration initiative. Teachers were trained in technology integration and subsequently began using technology in everyday general education lectures. Additionally, this curriculum includes a realistic technological assistance plan for instructors who deal with pupils who have disabilities. This method enables teachers to assist these pupils by meaningfully integrating digital resources into lessons. In the Etiwanda School District, the idea was a success. Due to this technological integration, children with unique learning challenges are now fulfilling their IEP targets more rapidly. Additionally, they are increasing their performance against district benchmarks (Courduff, 2011).

\subsection{METHODOLOGY}

\subsection{Research Design}

Research methodology is a set of tools, techniques, and procedures used during research. According to Howell (2013), a methodology is a strategy that shows the form of research and the methods that will be used to arrive at the results. These methods comprise processes and techniques that were employed in research to arrive at the results of the research. Methods employed for this study are discussed here under the following headings: research design, selection of subject, study population, sample size, sampling techniques, sources of data, data collection instruments, data collection procedure, data analysis, and ethics of researching. The study used a quantitative research design and a social survey research technique. According to Creswell (2012), survey researchers often pick and investigate a sample of a population and then generalize the results to the entire population. Surveys are advantageous because they are effective in describing the characteristics of a large population. This design provides the advantage of assessing current attitudes or behaviors. It provides data in a compressed time frame, such as the time necessary to conduct the survey and collect the data. No other research approach possesses this breadth of capacity, which enables a more exact sample to be constructed to form conclusions and make critical choices. Due to the secrecy of surveys, respondents can provide more honest and meaningful responses. Surveys performed anonymously provide a more legitimate and unambiguous channel for responses than other types of research philosophies, particularly if it is explicitly stated that survey responses remained completely categorized. However, surveys rely on standardization, which is inflexible because it requires that the study's basic design remain constant throughout the data collection process (Fraenkel and Wallen, 2006).

\subsection{Situation of Technology-assisted learning in Chad}

The Republic of Chad is a landlocked country located in Central Africa. It borders Libya to the north. Niger, Nigeria, and Cameroon are in the west; the Central African Republic in the south; and the east of Sudan. Chad covers an area of square 1284000 miles and according to United Nations data, Chad's mid-2020 population is estimated to be $16,425,864$. The population of Chad is equivalent to $0.21 \%$ of the world's total population. Chad ranks 72 nd in the list of countries by population (and its dependencies). . French and Chadian Arabic are the official languages. This country is 50\% Muslim, 25\% Christian, and 25\% animists. For political and educational purposes, Chad merged two different countries into one country. Language, geography, religion, and economic criteria clearly distinguish these two parts. Northern Chad is barren land with desert-like characteristics The lack of adequate educational facilities continues to hinder progress towards this sustainable development goal, and access to technology continues to pose challenges in the Chadian education system.

However, access to educational technology in Africa is usually based on the donor model, in which machines in more developed countries are refurbished and then transported. Many well-known charities are running such programs, such as Camara (Ireland) and Computers 4 Africa (UK), and large organizations (such as Microsoft and Apple) also use donations as part of their charity programs.

Here is a study on the use of technology specifically on the use of computers to strengthen studies or help students carry out their research in Turkey, the similar study on the use of technology was done in Chad, and this study allows us to have an idea of how students are doing by relying on technology for their studies.

Ketchikan, O... (2015). EFL learners' attitudes towards using computers as language learning tools. The purpose of the research was to investigate the attitude of undergraduates at a private university towards using 
computers as a learning tool. In this regard, some variables that may be antecedents of attitudes toward computers are studied, including gender, computer experience, and perceived ability to use programs. The data was collected from 192 undergraduates enrolled in two core English courses (EN012 and EN 013). The tool of this research is the questionnaire. The results show that students have a positive attitude towards using computers as learning tools. Factors related to gender and computer experience will not affect students' attitudes, but the perception of using programs does affect their attitudes. We've got the same answers from our students in different universities and different English centers in N'Djamena, chad's capital. Access to technology is a big challenge in the Chadian education system as we mentioned above, from a young age, in primary and middle schools, students even teachers don't have full access to technology, technology at this stage is very expensive to have access, the conditions are not met (infrastructures) schools do not have the capacities to make available to students, there are no qualified teachers to teach students how technology is used, which is a major problem since they have not received training to know how to use it properly for studies, all education in Chad is held traditionally, the blackboard and chalk, students use copybook to write their lessons, which also does not allow teachers to do their research properly and finally to arrange their course to provide them. It is only when arriving at colleges that some qualified teachers who have been educated outside of Chad or even outside of Africa who have experience in the field of technology and who wish to teach, it is only they can teach students how the use of technology is done and how to do research which allows students to gradually understand the technology and therefore to use it for their research, often for class presentations. Arrived at the university now they have a little clear idea on technology but the problem of financial capacities, the acquisition of technological devices remains a problem for Chadian education, which unfortunately is a handicap for the educational system despite the desire of students to want more to discover what technology contains. It should also be noted a lack of qualified teachers in this field, lack of means to have technological materials, and the biggest shortcoming is the Internet, the cost of the Internet is very high so in some private schools and universities, they do their best so that some students can have internet access but efforts are always in vain due to the high blow of internet.

\subsection{Population}

Neuman (2006) defined a population as a large group of many cases from which a researcher draws a sample and generalizes the results of that sample. Alvi (2016) also referred to the population as all members of a particular group who meet certain criteria for a research study. The intended population for the study is made of lecturers and Level 400 undergraduate students across the 7 faculties. The Level 400 undergraduate students were selected due to their long stay at the university than any other level. The university has 540 lecturers and 16142 students in general across 7 faculties. Out of 16142 students, 900 are level 400 undergraduate students. This gives a total population of 1440 comprising 120 lectures and 900 level 400 undergraduate students.

\section{Table 3.1 Study Population}

\begin{tabular}{|l|l|l|l|}
\hline Institution & Lecturers & Level 400 Undergraduate Students & Total \\
\hline University of Ndjamena & 540 & 900 & 1440 \\
\hline
\end{tabular}

\subsection{Sample Size}

The choice of the sample was influenced by the assertion made by Fraenkel and Wallen (2000) that, when it is practicable, researchers would prefer to study the complete population in which they are interested. Usually, however, this is difficult to perform, because most populations are huge, diverse, and distributed over a large geographical area. Finding, let alone contacting, all the members can be time-consuming and expensive. For that reason, of necessity, a researcher can select the sample for the study based on his capability and constrain to collect data for the study. According to Neuman (2006), the sample size is a subset of cases drawn from a larger pool that the researcher generalizes to the population. The researcher chose the sample size for this study using Alreck and Settle's sampling ratios (cited in Ankrah, 2014, p. 121). They proposed that for different population sizes; a sampling ratio of $30 \%$ is adequate for a population of less than 1,000 ; a sampling ratio of $20 \%$ is adequate for a population between 1,000 and 10,000 , and a sampling ratio of $10 \%$ is adequate for a population greater than 10,000 . The researcher, therefore, selected a sample size of 288 which is $20 \%$ of 1440 comprising level 400 undergraduate students and 540 lecturers.

Sample size $(\mathrm{N})=20 / 100 \times 2854=\mathbf{2 8 8}$

\begin{tabular}{|l|l|l|l|l|l|l|}
\hline Institution & \multicolumn{3}{l|}{ Study Population } & \multicolumn{3}{l|}{ Number Sampled (20\%) } \\
\hline University of Ndjamena & Lectures & Student & Total & lectures & students & Total \\
\hline Total & 540 & 900 & 1440 & 108 & 180 & $\mathbf{2 8 8}$ \\
\hline
\end{tabular}

\subsection{Sampling Technique}

Sampling is the process or technique of selecting an appropriate sample, or representative of a population, to ascertain the traits or parameters of the entire population" (Neuman, 2006). The sampling was conducted to ensure that the items selected accurately represented the population from which they were obtained. Using sampling 
procedures, the researcher carefully picked the sample to ensure that it accurately represented the population. The convenience sampling technique was used to distribute questionnaires to lecturers and students in this study. Convenient sampling is a type of non-probability sampling in which a sample is drawn from a population segment that is nearby or readily available.

\subsection{ANALYSES AND FINDINGS}

\subsection{Quantitative Analyses of the Study}

This section consists of the quantitative analyses of the study based on the objectives of the study. It includes the descriptive statistics of the demographic data of respondents, descriptive analysis of the availability of teaching and learning technologies, the descriptive analysis of lecturers and students use of ICT in teaching and learning, and the responses of lecturers and students on the challenges to ICT integration in their teaching and learning activities.

Table 4.5 Teaching experience of Lecturers

\begin{tabular}{lcc}
\hline No. of Years & Frequency & Percentage \\
\hline $1-5$ & 20 & $18.5 \%$ \\
$6-10$ & 78 & $72 \%$ \\
$11-15$ & 10 & $9.5 \%$ \\
\hline Total & $\mathbf{1 0 0}$ & $\mathbf{1 0 0 \%}$ \\
\hline
\end{tabular}

Source: (fieldwork, 2021)

From the lecturers' survey, the majority of the respondents $78(72 \%)$ had 6-10 years of working experience. $20(18.5 \%)$ had $1-5$ years working experience and $10(9.5 \%)$ had $11-15$ years working experience as Lecturers. An indication that the majority $72 \%$ have 6-10 years of working experience in their institutions as shown in Table 4.5 .

\subsubsection{Availability of Technology Assisted Learning (TAL) tools}

The first research objective of the study was to examine the availability of Technology Assisted Learning Tools in Ndjamena Universities. Issues considered about this were; students' and lecturers' level of technology knowledge, ownership of technology by students and lecturers, access to computer and technology, access to the internet, and ICT facilities available for use in the lecture halls.

\subsubsection{Level of technological knowledge}

A person's level of technical knowledge reflects how well he or she understands, uses, and comprehends various tools and services. This enables us to assess the degree to which lecturers and students recognize, comprehend, and utilize available technological tools and services in their teaching and learning activities.

\subsection{Lecturer's level of ICT knowledge at appointment}

\begin{tabular}{lcc}
\hline Ratings & Frequency & Percentage \\
\hline Basic & 39 & 36 \\
Average & 60 & 55.5 \\
Good & 8 & 7 \\
Very good & 1 & 9.5 \\
\hline Total & & $\mathbf{1 0 0 \%}$
\end{tabular}

Source: (filed work, 2021)

Investigations were carried about lecturers' level of knowledge in technology before being appointed as a lecturer. All 108 lecturer respondents said Yes to having computer knowledge before coming to the university. Only $1(9.5 \%)$ scored very well. $60(55.5 \%)$ were average. $39(36 \%)$ have basic knowledge and $8(7 \%)$ rated good. Table 4.7

From the analysis above it can be seen clearly that at least half the number of lectures have a certain knowledge of technology before being appointed

\subsection{Lecturers Current Level of knowledge in Technology}

\begin{tabular}{lcc}
\hline Ratings & Frequency & Percentage \\
\hline Extremely improved & 12 & $11 \%$ \\
improved & 46 & $43 \%$ \\
Improved a bit & 50 & $46 \%$ \\
Still same & & $\mathbf{1 0 0 \%}$ \\
\hline Total & $\mathbf{1 0 0}$ & \\
\hline
\end{tabular}

Total

Table 4.6 illustrates that, out of 108, 50(46\%) responded to have an extremely improved upon their knowledge in technology after working in the university as a lecturer. 46(43\%) respondents indicated to improve upon their knowledge in technology. 12(11\%) responded to have extremely improved in their knowledge in technology. 
However, none responded to still having the same knowledge.

4.7 Lecturers Level of Participation in technology Training

\begin{tabular}{lcc}
\hline Ratings & Frequency & Percentage \\
\hline All modules & & \\
Few modules & 88 & $81 \%$ \\
never & 20 & $19 \%$ \\
\hline Total & $\mathbf{1 0 0}$ & $\mathbf{1 0 0 \%}$ \\
\hline
\end{tabular}

Source: (fieldwork, 2021)

To know their level of participation in technology training that took place in the institutions, lecturers were asked to indicate the number of modules they participated in. Out of the 108 , lecturer respondents, the majority 88 $(81 \%)$ have attended few training modules organized in their institution either by the ICT directorate, the library department, or any other department, and 20 (13\%) said they have never attended any of such pieces of training. These are illustrated in Table 4.7 The findings of the study indicate low patronage of technology pieces of training by lecturers.

Table 4.8 Students Level of technological Knowledge at Admission

\begin{tabular}{lcc}
\hline Ratings & Frequency & Percentage \\
\hline Basic & 15 & $8.3 \%$ \\
Average & 90 & $50 \%$ \\
Good & 60 & $33.5 \%$ \\
Very Good & 15 & $8.2 \%$ \\
\hline Total & $\mathbf{1 0 0}$ & $\mathbf{1 0 0 \%}$ \\
\hline
\end{tabular}

Source: (fieldwork, 2021)

From the students ${ }^{e e}$ survey, students were asked if they had any computer knowledge before being admitted into the university and how they will rate their knowledge in computers. Out of 180 student respondents, $90(50 \%)$ responded had average knowledge about technology (ICT) before coming to the university while 60 (33.3\%) said to have good knowledge in technology before admission. $15(8.2 \%)$ responded to having very good knowledge in ICT and the reaming $15(33.3 \%)$ also responded to having just basic knowledge. This has been represented in table 4.8 above. From the findings, students of Ndjamena are not that naïve when it comes to the use of technology. More than half of the students sampled for the study have some technical knowledge.

\subsection{Students Current Level of ICT knowledge}

\begin{tabular}{lcc}
\hline Ratings & Frequency & Percentage \\
\hline Extremely improved & 5 & $8 \%$ \\
improved & 45 & $25 \%$ \\
Improved a bit & 100 & $56 \%$ \\
Still same & 30 & $11 \%$ \\
\hline Total & $\mathbf{1 0 0}$ & $\mathbf{1 0 0 \%}$ \\
\hline
\end{tabular}

Source: (fieldwork, 2021)

Throughout their stay in the university till the final year, $100(56 \%)$ said they improved a bit, $45(45 \%)$ have Improved, $30(11 \%)$ responded still same Improved a bit, and $56(11 \%) 5(8 \%)$ affirm that they have extremely improved their knowledge in ICT. This is shown in Table 4.9.

4.10 Students Level of Participation in ICT Training

\begin{tabular}{lcc}
\hline Ratings & Frequency & Percentage \\
\hline In all modules & 10 & $5.6 \%$ \\
Few of the modules & 20 & $11.1 \%$ \\
Never & 150 & $83.3 \%$ \\
\hline Total & $\mathbf{1 8 0}$ & $\mathbf{1 0 0 \%}$ \\
\hline
\end{tabular}

Source: (fieldwork, 2021)

To know the level of participation of students in ICT pieces of training that took place in the institutions, students were asked to indicate the number of modules they participated in. Out of 180 student respondents, the majority $150(83.3 \%)$ have never attended any ICT training organized in their institution either by the ICT directorate, the Library department, or any other department. 20 (11.1\%) attended a few modules and $10(5.6 \%)$ said they attended all. This explains the low rate of improvement in their knowledge of ICT since the majority of them have never attended any ICT training in their institutions as shown in Table 4.10

\subsubsection{Ownership of Computers}

The study enquired to know lecturers and students' preparedness to use ICT in their teaching and learning activities by finding out their ownership of computers and the mode of acquisition to know the institutional and individual efforts towards the use of computers. 


\subsection{Ownership of Computer by Lecturers}

\begin{tabular}{lcc}
\hline Ratings & Frequency & Percentage \\
\hline Yes & 107 & $99.1 \%$ \\
No & 1 & $0.1 \%$ \\
\hline Total & $\mathbf{1 0 8}$ & $\mathbf{1 0 0 \%}$ \\
\hline
\end{tabular}

Source: (field, work, 2021)

4.12 Ownership of Computer by Students

\begin{tabular}{lcc}
\hline Ratings & Frequency & Percentage \\
\hline Yes & 170 & $94.4 \%$ \\
No & 10 & $5.6 \%$ \\
\hline Total & $\mathbf{1 8 0}$ & $\mathbf{1 0 0 \%}$
\end{tabular}

Source: (fieldwork, 2021)

Out of 180 student respondents, $170(94.4 \%)$ said they have their computer and the remaining $10(5.6 \%)$ said they don't have their computer as shown in Table 4.12. 10 (5.6\%) of those who have their computer said they acquired it themselves.

\subsubsection{Access to a computer}

Table 4.13 Access to the computer by Lecturers

\begin{tabular}{lcc}
\hline Ratings & Frequency & Percentage \\
\hline Very often & 7 & $6.5 \%$ \\
often & 22 & $20 \%$ \\
Not often & 79 & $73.5 \%$ \\
Not at all & & \\
\hline Total & $\mathbf{1 0 8}$ & $\mathbf{1 0 0 \%}$ \\
\hline
\end{tabular}

Source: (fieldwork, 2021)

Regarding access to a computer, lecturers were also asked if there are enough computers in their institutions and how often they get access, out of 108 lecturers, the majority 79 (73.5\%) said Not often and $22(34.8 \%)$ responded often. $7(6.5 \%)$ responded very often. However, no lecturer responded to not at all. This shows that at least there is minimal access to a computer. This illustration is represented in table 4.13.

\subsubsection{Access to the Internet}

Table 4.13 Access to the Internet by Lecturers

\begin{tabular}{lcc}
\hline Ratings & Frequency & Percentage \\
\hline Daily & 20 & $18.5 \%$ \\
Twice a week & 88 & $81.5 \%$ \\
Monthly & & \\
Never & & \\
\hline Total & $\mathbf{1 0 8}$ & $\mathbf{1 0 0 \%}$ \\
\hline
\end{tabular}

Source: (fieldwork, 2021)

About the use of the internet services provided by the institutions, lecturers were asked how they get access to the internet. All 108 lecturers affirmed that access to a computer laboratory or e-resource center and wifi services in their institution is very difficult. They were further probed to know how often they get access to the internet. The majority $88(32.3 \%)$ said daily and 4(17.7) said twice in a week as shown in Table 4.19. None of the lecturers responded monthly or never. These results indicate that the use of internet service to teach is very poor.

Table 4.14 Access to the internet by students

\begin{tabular}{lcc}
\hline Ratings & Frequency & Percentage \\
\hline Daily & 10 & $5.5 \%$ \\
Twice a week & 100 & $55.5 \%$ \\
Monthly & 70 & $39 \%$ \\
Never & & \\
\hline Total & $\mathbf{1 8 0}$ & $100 \%$ \\
\hline
\end{tabular}

Source: (fieldwork, 2021)

Regarding the survey on students' access to the internet, 100(55.5\%) students responded that they do access the internet twice a week. $70(39 \%)$ monthly and 10(5.5\%) daily. From the response above, internet usage is quite very low. This reflects the poor use of technology-assisted learning tools in teaching and learning as seen in Table 


\subsection{4 .}

\subsubsection{ICT Facilities Available in Lecture Halls}

This relates to the ICT tools and services that are available for lecturers and students to use in the lecture halls for their teaching and learning activities

Table 4.14 ICT Facilities available in lecture halls (Lecture response)

\begin{tabular}{lcc}
\hline ICT facilities & Frequency & Percentage \\
\hline Projector & 40 & $37 \%$ \\
Internet connection & 15 & $13 \%$ \\
TV/VCD/DVD/VCR & 26 & $24 \%$ \\
Computer & 23 & $22 \%$ \\
others & 4 & $4 \%$ \\
\hline Total & $\mathbf{1 0 8}$ & $\mathbf{1 0 0 \%}$ \\
\hline
\end{tabular}

Source: (fieldwork, 2021)

From table $4.1440(37 \%)$ lectures indicated to have projectors at the various lecture halls. $26(24 \%)$ indicated TV/VCD/DVD/VCR. 23(22\%) of the lecturers said they have computers at the lecture halls and $15(13 \%)$ responded to having internet connections. However, 4(4\%) of the lecturers indicated other facilities not captured in the answer provided. The halls are well equipped.

Table 4.15 ICT Facilities available in lecture halls (Student's response)

\begin{tabular}{lll}
\hline ICT facilities & Frequency & Percentage \\
\hline Projector & 100 & $56 \%$ \\
Internet connection & 60 & $33 \%$ \\
TV/VCD/DVD/VCR & 5 & $2.7 \%$ \\
Computer & 6 & $2.8 \%$ \\
Public address system & 9 & $5 \%$ \\
\hline Total & $\mathbf{1 8 0}$ & $\mathbf{1 0 0 \%}$ \\
\hline
\end{tabular}

Source: (fieldwork, 2021)

Out of the 108 student respondents, majority $100(56 \%)$ said they have computers in their lecture halls, $60(33 \%)$ said they have internet connections, 5 (2.7\%) said they have TV/VCD/DVD/VCR. $6(2.8)$ said they have a computer and $9(5 \%)$ said they have public address system as illustrated in Table 4.16.

4.2.4 Lecturers' and Students' Use of Technology-Assisted Learning Tools for Teaching and Learning The second research objective of the study was to examine lecturers and students' use of Technology Assisted learning tools for teaching and learning at Ndjamena University. Because of this, the researcher examined the use of ICT facilities, use of ICT software, use of ICT services, and use of learning management systems.

4.2.4.1.1 Ability to use Technology Assisted Learning Tools (TAL)

Regarding the ability of lecturers and students to use the available Technology Assisted Learning tools in their teaching and learning activities. Lecturers and students were asked if they use the available facilities and whether they can use them themselves or through the help of other people such as anyone with knowledge in TAL they come across, through the help of teaching assistants or friends, etc. as shown in Table 4.16 and Figure 4.17

Table 4.16 Lecturers' Ability to use Technology-Assisted Learning Tools.

\begin{tabular}{lll}
\hline Ratings & Frequency & Percentage \\
\hline Self & 10 & $9 \%$ \\
Teaching Assistants & 18 & $17 \%$ \\
Anyone with Knowledge in ICT & 50 & $46 \%$ \\
ICT experts in the institution & 30 & $28 \%$ \\
\hline Total & $\mathbf{1 0 8}$ & $\mathbf{1 0 0 \%}$
\end{tabular}

Source: (fieldwork, 2021)

In the application of the available TAL facilities such as the computer, projector, internet etc lecturers were asked if they apply them themselves or through the help of somebody, majority $50(46 \%)$ said they apply it through anyone with knowledge in technology. 30(28\%) said through the help of the ICT expert in the institution. With the help of Teaching Assistants, 10 (9\%) said they apply the facilities themselves, and $18(17 \%)$ said through teaching assistants. 
Table 4.17 Students' Ability to use Technology Assisted Learning Tools.

\begin{tabular}{lll}
\hline Ratings & Frequency & Percentage \\
\hline Self & 22 & 12.2 \\
Friends & 30 & 16.7 \\
Anyone with Knowledge in ICT & 88 & 48.8 \\
ICT experts in the institution & 40 & 22.3 \\
\hline Total & $\mathbf{1 8 0}$ & $\mathbf{1 0 0 \%}$ \\
\hline
\end{tabular}

Source: (fieldwork 2021)

Students' response to these questions about their ability to use TAL facilities is illustrated in Table 4.17 4.4. According to the results from the students' survey, $88(48.8 \%)$ said they apply it through the help of anyone with knowledge in TAL, 40 (22.3\%) said they can apply it through ICT experts in the institution, $30(16.7 \%)$ said they apply it through the help of friends and $22(12.2 \%)$ said through themselves.

4.2.4.1.2 Frequency of Use of TAL Facilities

The frequency of use of every tool plays a major role in the individual mastery of the use of that particular tool. To ascertain how frequent lecturers and students use ICT tools in their teaching and learning activities, they were asked the number of times they use the facilities as shown in Table 4.18and Table 4.19

Table 4.18 Lecturers frequency use of TAL

\begin{tabular}{lll}
\hline Ratings & Frequency & Percentage \\
\hline Everyday & 10 & $9.6 \%$ \\
Few times in semester & 8 & $7 \%$ \\
Only for notes and assignments & 90 & $83.4 \%$
\end{tabular}

Never

Total $108 \quad 100 \%$

Source: (fieldwork, 2021)

Concerning the frequency of use of TAL for teaching purposes by lecturers, the lecturers were asked to specify how frequently they use the available TAL facilities for teaching purposes, out of 108 lecturer respondents, the majority $90(83.4 \%)$ reported using ICT/computer only for teaching and notes. $10(9.6 \%)$ use it every day. $8(7 \%)$ use it a few times in the semester. There was no response on never This is illustrated in Table 4.18.

Table 4.19 students' frequency use of TAL

\begin{tabular}{lll}
\hline Ratings & Frequency & Percentage \\
\hline Everyday & 10 & $9.6 \%$ \\
Few times in semester & 8 & $7 \%$ \\
Only for notes and assignments & 90 & $83.4 \%$
\end{tabular}

Never

$\begin{array}{lll}\text { Total } & 180 & 100 \%\end{array}$

Source: (fieldwork, 2021)

Concerning the frequency of use of TAL for learning purposes by students, the students were asked to specify how frequent they use the available TAL facilities for learning purposes, out of 180 student respondents, majority $90(83.4 \%)$ reported using ICT/computer for learning purposes every day, $8(7 \%)$ uses it few times in a semester. $10(9.6 \%)$ use it only for assignments and lesson notes and $29(5.7 \%)$

4.2.4.2 Use of ICT Software by Lecturers and Students

To be skilled enough to apply ICT to one's activities require one to have a fair knowledge of the functions and use of basic computer software. Because of this, lecturers and students were asked to indicate how familiar they are with listed ICT software and those that are not listed.

Table 4.20 Use of ICT software by lectures

\begin{tabular}{|l|l|l|l|l|l|l|}
\hline Software & Excellent & Good & Average & Poor & Very poor & Total \\
\hline $\begin{array}{l}\text { Word processors (Ms. Word, Word } \\
\text { Perfect, etc.) }\end{array}$ & $15(13.9 \%)$ & $10(9.2)$ & $56(52)$ & $15(13.9)$ & $12(11 \%)$ & $100 \%$ \\
\hline $\begin{array}{l}\text { Spreadsheet and statistical packages } \\
\text { (Ms Excel,SPSS, Epi-info, etc) }\end{array}$ & $10(9.2)$ & $15(13.9 \%)$ & $5(4.6 \%)$ & $60(55.6 \%)$ & $18(16.7)$ & $100 \%$ \\
\hline Presentation (PowerPoint etc) & $30(27.8)$ & $5(4.6 \%)$ & $64(59.2)$ & $9(8.4)$ & & $100 \%$ \\
\hline $\begin{array}{l}\text { Database management system (Ms } \\
\text { Access, Oracle etc) }\end{array}$ & $5(4.6)$ & $11(10.2 \%)$ & $25(23 \%)$ & $30(27.8)$ & $37(34.4)$ & $100 \%$ \\
\hline Programming Language & $3(2.8 \%)$ & $10(9.3 \%)$ & $10(9.2 \%)$ & $45(41.7 \%)$ & $40(37 \%)$ & $100 \%$ \\
\hline Internet Surfing/ browsing & $4(3.7 \%)$ & $20(18.5 \%)$ & $70(64.8 \%)$ & $10(9.2 \%)$ & $4(3.7 \%)$ & $100 \%$ \\
\hline Internet Design & $2(1.9 \%)$ & $5(4.6 \%)$ & $23(21 \%)$ & $40(37 \%)$ & $40(37 \%)$ & $100 \%$ \\
\hline
\end{tabular}

Source: (fieldwork, 2021) 
Regarding software applications by lecturers, lecturers were more familiar with internet use, PowerPoint, and Word application. This result is also in agreement with Chapman (2003) who found that most teachers reported integrating word processing into their teaching. Database application, programming, and internet design were least integrated into teaching since lecturers are least familiar with them. This result is in agreement with (Albirini, 2006) who found that majority of teachers were not using database applications in their teaching due to a lack of the required skills to use them.

Table 4.21 Use of TAL software by students

\begin{tabular}{|l|l|l|l|l|l|l|}
\hline Software & Excellent & Good & Average & Poor & Very poor & Total \\
\hline $\begin{array}{l}\text { Word processors (Ms Word, } \\
\text { Word Perfect etc.) }\end{array}$ & $5(2.8 \%)$ & $80(44.4 \%)$ & $70(38.9$ & $15(8.3 \%)$ & $10(5.6 \%)$ & $100 \%$ \\
\hline $\begin{array}{l}\text { Spreadsheet and statistical } \\
\text { packages } \\
\text { (Ms Excel,SPSS, Epi-info, etc) }\end{array}$ & $10(5.6 \%)$ & $35(19.4 \%)$ & $45(25 \%)$ & $85(47.2)$ & $5(2.8 \%)$ & $100 \%$ \\
\hline Presentation (PowerPoint etc) & $30(16.7 \%)$ & $100(55.6 \%)$ & $30(16.5 \%)$ & $10(5.6 \%)$ & $10(5.6 \%)$ & $100 \%$ \\
\hline $\begin{array}{l}\text { Database management system } \\
\text { (Ms Access, Oracle etc) }\end{array}$ & $12(6.6 \%)$ & $35(19.6)$ & $58(32.23 \%)$ & $75(41.67)$ & & $100 \%$ \\
\hline Programming Language & $3(1.7 \%)$ & $10(5.6 \%)$ & $10(5.6 \%)$ & $86(47.7 \%)$ & $71(39.4 \%)$ & $100 \%$ \\
\hline Internet Surfing/ browsing & $20(11.1 \%)$ & $20(11.1 \%)$ & $85(47.2 \%)$ & $50(27.8 \%)$ & $5(2.8 \%)$ & $100 \%$ \\
\hline Internet Design & $1(0.5)$ & $5(2.8)$ & $24(13.3 \%)$ & $100(55.6 \%)$ & $50(27.8 \%)$ & $100 \%$ \\
\hline
\end{tabular}

Students were asked to rate their ICT skills on a four-point Likert-type scale ranging from "Excellent (1)" to "Very Poor (5)". majority of the respondents were good in word processor $80(44.4 \%)$ and in PowerPoint presentation 100(55.6\%), On the other hand, the majority of the respondents perceived their skill in the database as "low" or "Poor" in the internet design, database management, and programming language. The result is in agreement with Jegede et al. (2007) and Lau and Sim (2008) who found students and teachers are more proficient in word processing than the other applications.

Lecturers were further probed on the challenges to effectively integrate TAL in teaching and learning through a four-Likert-scale from "Not Affected to adversely affected". According to the results of the study, out of 108 lecturers, 90(83.4) indicated poor governmental support is one of the greatest challenges. Another great challenge being identified from the survey is poor internet connections to the various computers available representing $80974.1 \%$ ). 85(78.7\%) of lecturers affirm inadequate material on the use of TAL to teach.

Table 4.23 Students View on Challenges to ICT integration in teaching and learning.

\begin{tabular}{|r|l|l|l|l|l|}
\hline \multirow{2}{*}{ SN } & & \multicolumn{1}{|c|}{ QUESTION } & & & \\
& & &
\end{tabular}

Source:(fieldwork,2021)

According to the results of the study, student respondents ${ }^{\text {Iee }}$ view on ICT integration in teaching and learning 
were as follows:140 (77.7\%) said ICT integration in teaching and learning is adversely affected by insufficient internet bandwidth or speed. $150(83.3 \%)$ are of the view that it is affected by the insufficient interactive whiteboard. 85(47.2\%) said it is partially affected by lack of adequate skills of teachers and 71 (14\%) school computers are out of date and $60(30.5 \%)$ of the respondents has indicated that an insufficient number of computers has adversely affected TAL integration into teaching and learning.

\subsection{Discussion of findings}

\subsubsection{Availability of Technology Assisted Learning (TAL) tools}

Sutherland et al (2004) suggest that a smart place to start for teachers who want to integrate ICT into their subject teaching is to creatively exploit easily available ICT hardware/software for teaching and learning. Because of this, issues considered were; students' and lecturers' level of ICT knowledge, ownership of computers by students and lecturers, access to the computer, access to the internet, and ICT facilities available for use in the lecture halls.

According to the study's findings, all instructors have their computers, however, this cannot be said of the students, even though the majority of them have. They were then questioned about the source of their computers, and none of the students named the institution. The institution was only referenced by a few speakers as a source. Observation revealed that those computers were purchased for departments for lecturers to use during their lecture periods, implying that no single professor owns those computers and that their use is restricted to the benefit of any single lecturer. This means that neither university is benefiting from any laptop effort.

Furthermore, while projectors and computers are available in all lecture halls, the response to additional ICT amenities such as public address systems, television, and VCD/DVD/VCR was not positive. Based on the findings, it can be stated that Ndjamena University has insufficient ICT facilities to facilitate teaching and learning. This is following the findings of Owusu-(2015) Ansah's research of information and communication technology resources in Chadianian polytechnic libraries. The majority of respondents recruited from ten polytechnic libraries did not have ICT facilities in their libraries, indicating that those libraries are unable to serve current academic library services that are anticipated to provide value-added services to users.

According to Mishra and Koehler (2006), successful and efficient integration of ICT in teaching and learning requires the careful interweaving of technology expertise, pedagogic knowledge, and content knowledge. When the necessary ICT facilities are absent or in short supply, it is impossible to integrate ICT into teaching and learning. The availability of technology is therefore critical to a successful integration since it serves as the platform for achieving teaching and learning that transcends time and geographical constraints. If ICT facilities are not available to help teaching and learning, it is impossible to use the potential of ICT to support teaching and learning. In addition to having ICT facilities available, tight strategies should be implemented to ensure that they are used to their full potential. This is because simply providing ICT infrastructure without assuring their use will not allow them to reach their full potential.

\subsubsection{Lecturers' and Students' Use of Technology-Assisted Learning Tools for Teaching and Learning}

The study's second goal is to look into how lecturers and students use ICT for teaching and learning. The framework of this study was the Technological, Pedagogic, Content Knowledge Theory (TPAC), which looked at the interpretational role of the aspects of teaching and learning to achieve successful knowledge transmission. According to Mishra and Koehler (2006), the success of every teaching and learning activity is determined by the lecturer's perfect balance of content knowledge, pedagogic expertise, and technology knowledge. As a result, the researcher investigated the use of ICT in teaching and learning in terms of ICT facilities, ICT software, ICT services, and the usage of a learning management system. In terms of lecturers' and students' abilities to use accessible TAL facilities in their teaching and learning activities, the study's findings revealed that the majority of lecturers and students are unable to use their ICT tools independently. This indicates that these professors and students are unable to successfully integrate TAL.

Agordzo, et'l (2020). Appropriateness refers to the ways in which facilitators need to match the learning experience to each student's current state of knowledge and understanding, and at the equal time guaranteeing that the learning activities actually foster the desired educational outcomes. This implies monitoring of students' progress, presenting quick corrective feedback, structuring and presenting activities to facilitate meaningful learning, and ensuring that cognitive processes being fostered.

According to Graham (2011), a teacher's skill to set up TAL tools correctly has an impact on how they are used in the teaching process. Any teaching and learning activity's outcome is likely to be influenced by the tools used to carry out the activity, as well as the individual user's skills and understanding of how to utilize the tool effectively. As a result, it is critical that students' and lecturers' ICT abilities, as well as their interest in ICT, be prioritized to encourage their use of ICT to improve teaching and learning.

The study's findings are consistent with Obiri-Yeboah et al's (2013) study at KNUST on the factors influencing ICT adoption in Chadian's higher institutions. ICT was not properly integrated into research, teaching, or learning, according to the findings. Inadequate infrastructure and ICT skills were also mentioned as major barriers. However, though more than half of the lecturers indicated applying TAL during teaching, quite an 
appreciable number of them do not. Although the study proved that most lecturers were ICT literate, only a few of them rated their skills as being good and only a few of the ICT facilities are applied in their teaching. According to the study's findings, both professors and students are interested in TAL-integrated teaching and learning, as evidenced by their computer ownership and internet usage. This conclusion supports Noor-Ul-(2013) Amin's claim that the adoption and usage of ICTs in education has a good impact on teaching, learning, and research, which can affect educational delivery and enable wider access to education. Even though the majority of people utilize ICT daily, they frequently use it for purposes other than academics. This could be because they don't know how to apply it to their academic goals. As a result, students must be taught how to use TAL for academic objectives in a practical manner.

Word processing and PowerPoint were the most popular in terms of familiarity and use of application software in the teaching and learning process. In terms of skill levels, both students and lecturers are proficient in the usage of word processors and PowerPoint, and a few are also competent in spreadsheets (Microsoft Excel) and SPSS. Concerning ICT services. The findings of the study revealed that a large number of lecturers and students use the internet mostly for research, email, lecture notes, surfing, and Facebook when it comes to ICT services, which are mostly characterized by Internet use for teaching and learning. The majority of pupils also utilize it to watch YouTube lessons and complete assignments. According to observations, the majority of those who use it for Facebook does not use it for academic purposes and do not use it for video conversations, which can be used for debates. Observations revealed that their usage of these services for academic reasons is somewhat limited, even though all of these uses improve teaching and learning. This backs up Akeriwe et al (2015)'s work in UDS on employing mobile technologies for social media-based library services. Respondents were asked to indicate whether they used or did not use applications, as well as how often they used them, to determine their familiarity with social media in general, taking into account ICT tools such as iPads, laptops, mobile phones, and ICT services such as Dropbox, Skype, and Whatsapp. They didn't use the tools, it was discovered. And the biggest reason given by respondents was that they could not use them. This means that awareness isn't the same as application. Lecturers and students may be aware of the presence and use of certain ICT facilities, but they may not be aware of how to use them effectively. According to the study's theory, effective integration of technology into teaching and learning requires the actual use of technology in teaching and learning with comprehension.

4.3.3 Challenges encountered in integrating Technology Assisted Learning (TAL) into teaching and learning The third objective of this study was to identify challenges to TAL integration in teaching and learning at Ndjamena University.

The study's findings revealed several barriers to ICT integration in teaching and learning, including power outages, system breakdowns, a lack of maintenance, and virus attacks, among other things. Low internet speed, insufficient ICT facilities, a lack of pedagogical models on how to use ICT for teaching and learning, and other problems were discovered in the study. This is due in part to the high cost of implementing ICT in Chadian's universities, including the high cost of hardware and software, the high cost of establishing telecommunication networks, and the high cost of maintaining and repairing infrastructure, which makes it unaffordable for developing countries. This is also supported by Bingimlas' (2009) study on the impediments to successful ICT integration in teaching and learning. Their study, on the other hand, did not find a paucity of pedagogical models for using ICT for teaching and learning, as this study found. This is a critical element because the majority of the challenges reported concerning the underutilization of existing resources are due to lecturers' and students' inability to use them.

\subsubsection{Measures to improve the use of Technology Assisted Learning (TAL) in teaching and learning.}

Effective use of ICT in education requires inter-and intra-ministry coordination, as well as strong leadership with a clear vision. Developing national ICT master plans can provide a framework for better coordination. Technical support for teachers is crucial to not only install but maintain both hardware and software. They can provide an enabling environment for teachers to focus on teaching by minimizing their technical tasks. Teachers are overloaded with multiple tasks and often see ICT in education as extra work rather than a new opportunity. Shortterm strategies are needed to develop their capacity for implementing ICT-enabled lessons. Just-in-time professional development can allow teachers to receive training when needed. Personalized support from an offsite helpdesk can be provided via SMS and mobile communication applications. Additional conditions must be completed for TAL investments to benefit pupils. School regulations must ensure that schools have the bare minimum of ICT infrastructure, including reliable and cheap internet access as well as security features such as filters and site blocks. Basic ICT literacy abilities, ICT use in pedagogical settings, and discipline-specific uses should all be addressed in teacher policies. Integration of TAL in the curriculum is required for successful ICT implementation. Finally, digital material must be created in local languages and reflect the culture of the region. To enable access and efficient use of TAL, ongoing technical, human, and organizational support is required on all of these concerns. 


\subsubsection{Availability of Technology Assisted Learning (TAL) tools}

The study's findings revealed that projectors, computers, and the internet are the most common ICT tools used in lecture halls for teaching and learning. Furthermore, available computers are typically owned by people, whereas the university provides the projector and internet.

\subsubsection{Lecturers' and Students' use of Technology Assisted Learning Tools for Teaching and Learning}

This aspect focused on lecturers' and students' use of TAL for teaching and learning in terms of use of facilities, use of ICT services, and use of application software. About lecturers and students' usage of ICT facilities. The study's findings revealed that the majority of lecturers are unable to operate existing ICT tools, implying that these lecturers and students are unable to successfully use or incorporate ICT in their teaching and learning activities. The outcomes of the survey revealed that both students and lecturers are comfortable with word processing software, PowerPoint presentations, and Excel tools when it comes to the usage of ICT software. Databases, programming, and web design, among other things, were the least integrated. Because lecturers are unfamiliar with database applications and programming, they were the least incorporated into instruction. In terms of TAL tools services, the survey found that both students and instructors felt comfortable utilizing the internet for research, email, lecture notes, internet surfing/browsing, and Facebook. Observations revealed that their usage of these services for academic reasons is rather modest, even though all of these applications improve teaching and learning. 5.2.3 Challenges encountered in integrating Technology Assisted Learning (TAL) into teaching and learning. The third objective of this study was to identify challenges to TAL integration in teaching and learning at Ndjamena University.

The study's findings revealed several barriers to ICT integration in teaching and learning, including power outages, system breakdowns, a lack of maintenance, and virus attacks, among other things. Low internet speed, insufficient ICT facilities, a lack of pedagogical models on how to use ICT for teaching and learning, and other problems were discovered in the study. This is due in part to the high cost of implementing ICT in Chadian's universities, including the high cost of hardware and software, the high cost of establishing telecommunication networks, and the high cost of maintaining and repairing infrastructure, which makes it unaffordable for developing countries. This is also supported by Bingimlas' (2009) study on the impediments to successful ICT integration in teaching and learning. Their study, on the other hand, did not find a paucity of pedagogical models for using ICT for teaching and learning, as this study found. This is a critical element since the majority of the difficulties reported regarding the underutilization of existing resources are due to lecturers' and students' incapacity to use them.

\subsubsection{Measures to improve the use of Technology Assisted Learning (TAL) in teaching and learning.}

The last objective of the study was to find measures to improve the integration of TAL.

From the respondents, training was discovered to be one of the most important ideas proposed to achieve the proper integration of TAL into teaching and learning. Others are financial support, workshops for students on the use of technology in learning. Another vital point captured is the issue of outdated computers and software. There is the need to install new and updated computers to support the current.

From the interview gathered, another key measure is stakeholder support. Technology in education is demanding and cannot lie solely on the shoulders of institutions alone. IT tech giants' companies, service providers need to come on board to help the institutions. Financial support is seriously needed. Educational technologies are very expensive, there is the need to call for support where the institution cannot foot the cost alone. Colleges and lower institutions need to make ICT education very compulsory. This will give students first-hand knowledge before entering the university.

\subsection{Conclusion}

Technology-Assisted Learning (TAL) tools for teaching and learning need to be significantly improved at Ndjamena University. To improve access among students and lecturers, every faculty, department, and lecture hall should make a concerted effort to provide appropriate TAL facilities. It is critical to model teaching techniques around the demands of the business for graduates to obtain the requisite skills required by the industry in Chad, and particularly in developing nations, to improve technology development. In this regard, lecturers must update and enhance their learning process model beyond the old transmission paradigm by incorporating new technologies that will improve graduates' marketability. Because some students have strong ICT abilities, lecturers should be encouraged to include students during instruction in an ICT integrated environment. Instructors must provide a friendly and collaborative atmosphere where students may apply technology to their education while also improving technical abilities in our current day when many young students gain basic computer skills before entering university.

Based on the findings of the study, the following recommendations were made: The ICT Directorate at Ndjamena should collaborate to organize frequent ICT training programs for lecturers as a long-term ICT skills development measure, to improve their competence and encourage and motivate them to integrate relevant technologies into their teaching. This should be accompanied by a university-wide mandate and roadmap requiring instructors to include ICT into their presentations. Lecturers would be more likely to take the training program 
seriously as a result of this.

To inspire students, raise their confidence, acceptance, and use of ICT resources to promote their learning, ICT training at the Directorate should be enhanced and made a university prerequisite for graduation or a core course for all students. For example, to increase students' ICT abilities, the ICT directorate and library must be proactive and capable of organizing forums in which students may participate. For example, the librarian can instruct students on the materials accessible in the library as well as how to do research using various academic databases. This will alleviate the difficulty that students have when browsing the internet for information for their numerous tasks. Lecturers should also give students more assignments and involve them in activities that will require them to utilize ICT resources frequently. This is because, frequency of use of ICT tools, plays a major role in the individual mastery of the use of that tool in their activities. Internet access points, particularly wireless access points, should be increased to resident halls to improve and promote convenient online contact between lecturers and students, as well as among students, to foster learning outside the classroom.

The maintenance of the few ICT systems in existence should be prioritized so that professors and students can get the most out of them. Viral attacks and other difficulties will occur if they are not maintained regularly, resulting in system failure. When this happens, the institution's whole activities will be disrupted, and all of the money previously invested would be lost. The burden on Ndjamena University to integrate technology into teaching and learning needs much financial support. The government needs to support the institution with finance.

\section{References}

Albirini, A. (2006). An exploration of the factors associated with the attitudes of high school EFL teachers in Syria toward information and communication technology Unpublished dissertation). Ohio State University.

Al-Alwani, A. (2005). Barriers to Integrating Information Technology in Saudi Arabia Science Education. Doctoral dissertation, the University of Kansas, Kansas.

Agordzo, G. (2020). Using Multimedia Tools in Education (History Education in the Basic Schools, Ghana). International journal of scientific and engineering research, 11, 217-224.

Balanskat, A., Blamire, R., \& Kefala, S. (2006). A review of studies of ICT impact on schools in Europe: European Schoolnet.

Baytak, A., Tarman, B., \& Ayas, C. (2011). Experiencing technology integration in education: children's perceptions. International Electronic Journal of Elementary Education, 3(2), 139-151.

Bulut, O., \& Delen, E. (2011). The relationship between students' exposure to technology and their achievement in science and math. The Turkish Online Journal of Educational Technology, 10(3).

Coffey, G. (2012). Literacy and Technology: Integrating Technology with Small Group, Peer-led Discussions of Literature. International Electronic Journal of Elementary Education, 4(2), 395-.

M. (2014). Vygotsky meets technology: A reinvention of collaboration in the early childhood mathematics classroom. Early Childhood Education Journal, 42(1), 57-65

Creswell, J. W. (2012). Educational research: Planning, conducting and evaluating Quantitative and qualitative research. Educational Research (4th Ed). Lincoln: University of Nebraska

Davies, R. S., \& West, R.E. (2013). Technology integration in schools. Handbook of Research on educational communications and technology (4th Edition). Provo: Brigham Young University.

Delamarter, S. (2005a). Theological educators and their concerns about technology. Teaching Theology and Religion, 8 (3), 131-143.

Healey, F.J. (1993). Statistics: A tool for Social Research, 3rd ed. Belmont; Wadsworth. Dominguez, A., Saenzde-Navarrete, J., de-Marcos, L., Fernández-Sanz, L., Pagés, C., \& MartínezHerráiz, J.-J. (2013). Gamifying learning experiences: Practical implications and outcomes. Computers \& Education, 63, 380-392.

Flewitt, R.S. (2011). "Bringing Ethnography to a Multimodal Investigation of Early Literacy in a Digital Age." Qualitative Research 11 (3): 293-310.

Fraenkel, J. R., \& Wallen, N. E. (2006). How to design and evaluate research in education. 4th ed. Boston: McGraw-Hill.

Fathima, S. (2013). Challenges of ICT in Teaching-Learning Process. International Journal of Engineering and Science, 2: 12, 51-54.

Gerring, J. (2007). Case study research: Principles and practices. Cambridge, UK: Cambridge University Press.

Jegede, P. O., Odusola, O. D, \& Ilori, M. O. (2007). Relationships between ICT competence and attitude Among Nigerian tertiary institution Lecturers. Educational Research and Review, 2(7), 172-175.

Herron, J. (2010). Implementation of technology in an elementary mathematics lesson: The experiences of preservice teachers at one university. STATE Journal, 19(1), 22-29.

Howell, K. E. (2013). Introduction to the philosophy of methodology. Sage.

IDB (2020). Social Policies in Response to Effects of COVID-19. Washington, DC.

Keser, H., Uzunboylu, H., \& Ozdamli, F. (2012). The trends in technology-supported collaborative learning studies in the 21st century. World Journal On Educational Technology, 3(2), 103-119. 
Korte, W. B., \& Hüsing, T. (2007). Benchmarking access and use of ICT in European schools 2006: Results from Head Teacher and A Classroom Teacher Surveys in 27 European countries. ELearning Papers, 2(1), 1-6.

Koehler, M. J., Mishra, P., Kereluik, K., Shin, T. S., \& Graham, C. R. (2014). The technological Pedagogical content knowledge framework. In Handbook of research on educational communications and technology. Springer, New York, NY.

Lau, C. T. \& Sim, C. H. (2008). Exploring the extent of ICT adoption among secondary teachers in Malaysia. International Journal of Computing and IT research, 2(2), 19-36.

Lin, W., \& Yang, S. (2011). Exploring students' perceptions of integrating Wiki technology and peer feedback into English writing courses. English Teaching: Practice and Critique,10(2), 88-

Miller, S. (2011). Student voices for change. Learning and Leading with Technology, 38(8), 20-23

Mishra, P., \& Koehler, M.J. (2006). Technological pedagogical content knowledge: A framework for teacher knowledge. Teacher College Record, 108, 1017-1054.

Koehler, M. J., \& Mishra, P. (2009). What is technological pedagogical content knowledge? Contemporary Issues in Technology and Teacher Education, 9(1), 60-70.

Leouro, M. B., Doutoum, M. A., \& Lang, D. (2018). Building a Smart education in developing countries: Case of Chad. International Journal of Innovation and Scientific Research, 9, 170-179.

Neuman, W. L. (2006). Social research methods: Qualitative and Quantitative Approaches. $6^{\text {th }}$ Ed. Boston: Pearson Education, Inc. Pp. 224-225, 241, 287-28.

Okojie, , C. M., Olinzock, A. A., \& Okojie-Boulder, T. C. (2019). The Pedagogy of Technology Integration. The Journal of Technology Studies, 66-69.

Pelgrum, W. J., \& Law, N. (2003). ICT in Education around the World: Trends, Problems, and Prospects. Paris: UNESCO.

Rohlfing, I. (2008). What you see and what you get: Pitfalls and principles of nested analysis in comparative research. Comparative Political Studies. 91(11), 1492- 1514

Rosen, L. D. (2011). Teaching the iGeneration. Educational Leadership, 68(5), 10-15

Tondeur, H. V., Keer, J., \& Valcke, M. (2008). ICT integration in the classroom: challenging the potential of a school policy. Computers \& Education, 212-223.

Toprakci, E. (2006). Obstacles at the integration of schools into information and Communication technologies by taking into consideration the opinions of the teachers and principals of primary and secondary schools in Turkey. Journal of Instructional Science and Technology (e-JIST), 9(1),

Yemothy,N.E.(2015). Improving educational technology integration in the classroom. Doctoral Thesis: Walden University. 